\title{
Case report on congenital hypothyroidism: Early Vs Late Presentation
}

\author{
Maya Menon' ${ }^{1}$, Sreejyothi.G ${ }^{2}$, Deepa Binod ${ }^{3}$, Raveendranath $K^{4}, \operatorname{Riaz}^{5}$
}

${ }^{1}$ Dr. Maya Menon Associate Professor, ${ }^{2}$ Dr. Sreejyothi. G Assistant Professor, ${ }^{3}$ Dr. Deepa Binod Assistant Professor, ${ }^{4}$ Dr. Raveendranath. K Professor and HOD Department of Paediatrics SUT Academy of Medical Sciences, TVM.

${ }^{5}$ Dr. Riaz. I Assistant Professor, Paediatric Endocrinologist,Department of Paediatrics, Govt. Medical College, Trivandrum, Kerala, India.

Address for Correspondence: Dr. Maya Menon, dr.mayamenon94@gmail.com

\begin{abstract}
Most cases of congenital hypothyroidism are not hereditary and result from some form of thyroid dysgenesis. Thyroid dysgenesis can be aplasia, hypoplasia or an ectopic thyroid. Here we report two cases of thyroid dysgenesis presenting in different age groups.
\end{abstract}

Key Words: Hypothyroidism, Thyroid Dysgenesis, Ectopic Thyroid, Lingual Thyroid, Thyroid aplasia

\section{Introduction}

Some form of thyroid dysgenesis is the most common cause of permanent congenital hypothyroidism accounting for 80 to $85 \%$ of cases [1,2]. Most infants with congenital hypothyroidism are asymptomatic at birth even if there is complete agenesis of thyroid gland [3]. This situation is attributed to partial transplacental passage of maternal T4 which provides foetal levels that are approximately $33 \%$ of normal at birth [3]. Despite the maternal contribution of $\mathrm{T} 4$, hypothyroid infants still have a low serum T4 and elevated TSH level \& so will be identified by newborn screening programme.

Thyroid ectopy is a rare embryological anomaly characterized by the presence of thyroid tissue outside its normal position resulting from a defect in the thyroid diverticulum migration from failure of thyroid gland to descend from the foramen caecum to its normal prelaryngeal site [4].

Manuscript received: $18^{\text {th }}$ Jan 2016

Reviewed: $01^{\text {st }}$ Feb 2016

Author Corrected; $09^{\text {th }}$ Feb 2016

Accepted for Publication: $19^{\text {th }}$ Feb 2016
Here we report two cases of thyroid dysgenesis occurring in different age groups - Thyroid aplasia and Lingual Thyroid. Lingual Thyroid, a rare form of thyroid dysgenesis was detected in a four year old child with normal growth and development.

\section{Case report}

\section{Case 1}

A 4yr old child presented to our OPD with h/o mild fever of 2 days duration. She was active \& cheerful with normal growth \& development. During the visit her mother casually mentioned about on \& off constipation which urged us to send serum TSH. TSH came as $>100 \mathrm{mIu} / \mathrm{L}$. Since her growth \& development was normal we repeated the thyroid profile which confirmed $\mathrm{TSH}>100$, free $\mathrm{T} 4-0.7 \mathrm{ng} / \mathrm{dl}$, T4 $6.5 \mu \mathrm{g} / \mathrm{dl}$. Considering her age, antimicrosomal antibodies and antithyroglobulin antibody were also sent to rule out acquired hypothyroidism. These came as normal. Ultrasound neck was inconclusive. As per expert advice from pediatric endocrinologist Tc $99 \mathrm{~m}$ 
pertechnate scan was done which revealed an ectopic thyroid higher in the midline (Lingual) (Fig. 1). She was started on T4 and was asked to repeat TSH after 4 weeks. Repeat TSH dropped down to $<20 \mathrm{MIU} / \mathrm{L}$ with normal free T4. She is on close follow up with us as well as with paediatric endocrinologist. (The dose of T4 is being titrated based on free T4 and TSH levels). Her ectopic thyroid tissue helped her to attain normal growth \& development till now.

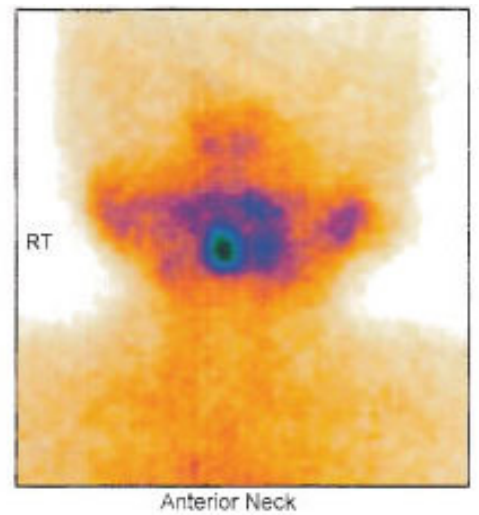

Fig. 1: Tc. Scan showing Lingual thyroid

\section{Case 2}

Reporting another common case of congenital hypothyroidism before routine neonatal screening was introduced in our hospital. She was born as a late preterm AGA with uneventful postnatal period. She was lost for follow up and came back to our opd at 2 month of age. She was noted to have skin mottling open mouth $\&$ a delay in social smile. Investigations showed a TSH $>150 \mathrm{mIu} / 1$. Ultrasound could not visualize thyroid. T4 was immediately started at a dose of $15 \mu \mathrm{g} / \mathrm{kg} /$ day. Technetium scan was delayed till 3 yrs since T4 replacement could not be even transiently stopped (for Tc scan) in a child below 3 yrs. TSH \& free T4 normalized soon and the dose of T4 was carefully titrated to avoid under or over treatment. Her growth \& development was also carefully monitored. Now at 3 yrs she is euthyroid on T4 with bone age corresponding to chronological age \& no stunting. Her development including speech\& hearing is normal. Technetium scan done at 3 yrs did not show any functioning thyroid tissue in the neck or at ectopic sites. So thyroid aplasia was confirmed. (Fig. 2)

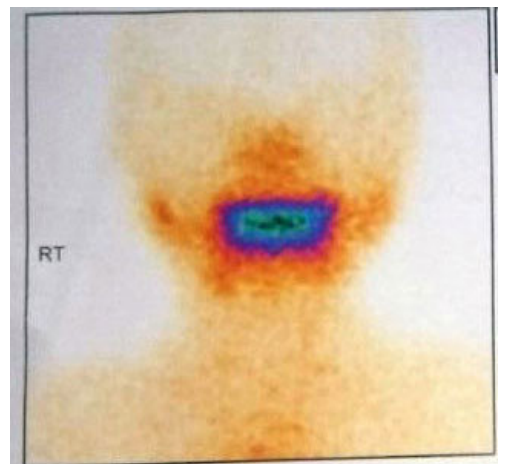

Fig.2: Tc. Scan showing Absent Thyroid

\section{Discussion}

Ectopic thyroid was described 1st in 1869 by Hickman in a newborn. Lingual thyroid represents $90 \%$ of ectopic thyroid $[5,6]$. Incidence is $1 / 100000-300000$ of the normal population mostly affecting females [7]. Lingual thyroid is defined as presence of thyroid tissue in the midline at the base of tongue anywhere between the circumvallate papillae and epiglottis [8]. Approximately $2 / 3 \mathrm{rd}$ of patient with lingual thyroid lack thyroid tissue in the neck $[5,9]$. The other sites are tracheal [10], lateral cervical [11] and sometimes submandibular [12], and exceptionally at oesophagus [13], heart and aorta[14], adrenal glands[15], pancreas[16], and gallbladder[17]. The pathogenesis of ectopic thyroid is still not clear. Some authors suggest maternal immunoglobulin directed against thyroid antigens as the cause of arrest of migration [18]. Molecular abnormalities are also involved in the thyroid development.

Some children with ectopic thyroid tissue produces adequate amounts of thyroid hormone for many years (or) it eventually fails in early childhood and children come to clinical attention because of a growing mass at the base of the tongue or in the midline (or) other symptoms of hypothyroidism. In case of our child, the ectopic thyroid was incidentally detected. She did not have any pressure symptoms (or) other symptoms 
significant enough to draw the clinician's attention to her ectopic thyroid. Her ectopic thyroid could have helped her maintain the normal thyroid status till now. Such cases can miss the neonatal screening tests as well. Regarding the other child with thyroid aplasia, such cases are diagnosed earlier and hardly missed nowadays because of Neonatal screening programme . In our hospital, we had few other cases of congenital hypothyroidism detected because of $\uparrow \mathrm{TSH}$ during neonatal screening programme which had turned out to be either thyroid aplasia (or) Transient hypothyroidism due to transplacental transfer of maternal antibodies (TRsAb)[19,20,21].

Most infants with congenital Hypothyroidism are asymptomatic even if there is complete agenesis of the gland. This is due to partial passage of maternal T4 $[3,19,22]$. Before neonatal screening programmes, congenital hypothyroidisms are rarely recognized in the newborns because signs and symptoms are usually not sufficiently developed. If suspected and diagnosis established early less characteristic manifestations are recognized. Wide $\mathrm{AF} \& \mathrm{PF}$ with prolongation of physiological jaundice $[3,23]$ may be noted in the neonatal period. Feeding difficulties, somnoloscence and sluggishness, hypothermia, mottled appearance [23] and umbilical hernia may be features in older infants. $10 \%$ of infants with congenital hypothyroidism can have associated congenital anomalies. Cardiac manifestations [6] are common. Retardation of mental \& physical development becomes greater during following months.

The diagnosis is confirmed by low serum levels of total \& free T4 and elevated TSH. Radiographs show delay in bone age (or) epiphyseal dysgenesis. Scintygraphy can help to pinpoint the underlying cause in infants with congenital hypothyroidism but treatment should not be unduly delayed for this study. I123sodium iodide is superior to $99 \mathrm{~m}$ Tc sodium pertechnate scan. All though ultrasonography is not accurate as radio nuclide scan in demonstrating ectopic glands, but studies have suggested that colour Doppler flow can detect up to $90 \%$ of cases of ectopic thyroid [24]. Demonstration of ectopic thyroid tissue suggests thyroid dysgenesis and establishes the need for lifelong T4 treatment. Failure to demonstrate any thyroid tissue indicates thyroid aplasia, but this also occurs in neonates with hypothyroidism caused by maternal antibodies (TRBAb) and in infants with iodide trapping defect.

Levothyroxine ( $\mathrm{L}-\mathrm{T} 4)$ given orally is the treatment of choice. The recommended initial starting dose in $10-$ $15 \mu \mathrm{g} / \mathrm{kg} /$ day for most term newborns $[25,26]$. Level of serum free T4 \& TSH levels should be monitored at recommended intervals. Serum TSH and free T4 should be measured every $1-2$ months in the 1 st 6 months of life and every $3-4$ months thereafter. For Lingual thyroid, usually levothyroxine therapy corrects hypothyroidism and also induces shrinkage of gland. If symptoms of bleeding or obstruction appears therapy by means of surgery or radio iodine ablation is warranted [27]. Surgical excision should not be attempted until adequate thyroid tissue is demonstrated in the neck [6].

\section{Conclusion}

Newborn screening tests helps in early detection and early initiation of treatment for congenital hypothyroidism. Some babies escape newborn screening and lab errors can occur. So awareness of early symptoms and signs are important and also some children with ectopic thyroid produces adequate amount of thyroid for many years so that they pass the initial neonatal screening tests and manifest later either with pressure symptoms (or) with other clinical features. Hence high index of clinical suspicion and knowledge of symptoms are important to diagnose congenital hypothyroidism early in children of all age group.

Funding: Nill, Conflict of Interest: None Permission of IRB: Yes 


\section{References}

1. De Felice M, Di Lauro R. Thyroid development and its disorders: genetics and molecular mechanisms. Endocr Rev. 2004 Oct;25(5):722-46.

2. Pankaj Agrawal, Rajeev Philip, Sanjay Saran, Manish Gutch, Mohd Sayed Razi, Puspalata Agroiya, Keshavkumar Gupta ${ }^{3}$ Congenital hypothyroidism: Indian Journal of Endocrinology and Metabolism Review Article 2015; 19(2): 221-227 DOI: $10.4103 / 2230-8210.131748$.

3. LaFranchi SH. Hypothyroidism. Pediatr Clin North Am. 1979 Feb;26(1):33-51.

4. Singhal P, Sharma KR, Singhal A. Lingual thyroid in children. J Indian Soc Pedod Prev Dent. 2011 JulSep;29(3):270-2. doi: 10.4103/0970-4388.85840.

5. Col SS Anand, Dr. Vikas Sood, Lt Col PG Kumar, Air Cmde KM Suryanarayna ,Lt Col Narender Kotwal Lingual Thyroid: MJAFI. 2006; 62 (2) : 184-185 DOI: http://dx.doi.org/10.1016/S0377-1237(06)80068-7.

6. Ibrahim NA, Fadeyibi IO. Ectopic thyroid: etiology, pathology and management. Hormones (Athens). 2011 Oct-Dec;10(4):261-9.

7. Arancibia P, Veliz J, Barria M, Pineda G. Lingual thyroid: report of three cases. Thyroid. 1998 Nov;8(11):1055-7.

8. Williams JD, Sclafani AP, Slupchinskij O, Douge C. Evaluation and management of the lingual thyroid gland.Ann Otol Rhinol Laryngol. 1996 Apr;105(4):3126.

9. Charles ND. Thyroid and whole-body imaging. In the thyroid, $5^{\text {th }}$ ed. Ed Ingbar and Braveman. Lippincot, Philadelphia, 1986; 458-78.

10. Hari CK, Brown MJ, Thompson I. Tall cell variant of papillary carcinoma arising from ectopic thyroid tissue in the trachea. J Laryngol Otol. 1999 Feb;113(2):183-5.

11. Choi JY, Kim JH. A case of an ectopic thyroid gland at the lateral neck masquerading as a metastatic papillary thyroid carcinoma. J Korean Med Sci. 2008 Jun;23(3):548-50. doi: 10.3346/jkms.2008.23.3.548.
12. Aguirre A, de la Piedra M, Ruiz R, Portilla J. Ectopic thyroid tissue in the submandibular region. Oral Surg Oral Med Oral Pathol. 1991 Jan;71(1):73-6.

13. Salam MA. Ectopic thyroid mass adherent to the oesophagus. J Laryngol Otol. 1992 Aug;106(8):746-7.

14. Ozpolat B, Dogan OV, Gökaslan G, Erekul S, Yücel E. Ectopic thyroid gland on the ascending aorta with a partial pericardial defect: report of a case. Surg Today. 2007;37(6):486-8. Epub 2007 May 28.

15. Hagiuda J, Kuroda I, Tsukamoto T, Ueno M, Yokota C, Hirose T, Deguchi N. Ectopic thyroid in an adrenal mass: a case report. BMC Urol. 2006 Aug $10 ; 6: 18$.

16. Eyüboğlu E, Kapan M, Ipek T, Ersan Y, Oz F. Ectopic thyroid in the abdomen: report of a case. Surg Today. 1999;29(5):472-4.

17. Liang K, Liu JF, Wang YH, Tang GC, Teng LH, Li F. Ectopic thyroid presenting as a gallbladder mass. Ann R Coll Surg Engl. 2010 May;92(4):W4-6. doi: $10.1308 / 147870810 X 12659688852473$.

18. Amani Mel A, Benabadji N, Benzian Z, Amani S. Ectopic lingual thyroid. Indian J Nucl Med. 2012 Apr;27(2):124-6. doi: 10.4103/0972-3919.110718.

19. Rastogi MV, LaFranchi SH. Congenital hypothyroidism. Orphanet J Rare Dis. 2010 Jun 10;5:17. doi: 10.1186/1750-1172-5-17.

20. Brown RS, Bellisario RL, Mitchell E, Keating P, Botero D. Detection of thyrotropin binding inhibitory activity in neonatal blood spots. J Clin Endocrinol Metab. 1993 Oct;77(4):1005-8.

21. Pacaud D, Huot C, Gattereau A, Brown RS, Glorieux J, Dussault JH, Van Vliet G. Outcome in three siblings with antibody-mediated transient congenital hypothyroidism. JPediatr. 1995;127 (2):275-277. doi: 10.1016/S0022-3476(95)70308-X.

22. Vulsma T, Gons MH, de Vijlder JJ. Maternalfetal transfer of thyroxine in congenital

hypothyroidism due to a total organification defect or thyroid agenesis. N Engl J Med. 1989 Jul 6;321(1):13-6. 
23. Grant DB, Smith I, Fuggle PW, Tokar S, Chapple J. Congenital hypothyroidism detected by neonatal screening: relationship between biochemical severity and early clinical features. ArchDisChild. 1992;67(1):87-90.

24. Ohnishi H, Sato H, Noda H, Inomata H, Sasaki N. Color Doppler ultrasonography: Diagnosis of ectopic thyroid gland in patients with congenital hypothyroidism caused by thyroid dysgenesis. J Clin Endocrinol Metab 2003;88:5145-9.

25. Selva KA, Mandel SH, Rien L, Sesser D, Miyahira R, Skeels M, Nelson JC, Lafranchi SH. Initial treatment dose of L-thyroxine in congenital hypothyroidism. J Pediatr. 2002 Dec;141(6):786-92.

26. American Academy of Pediatrics. Rose SR. Section on Endocrinology and Committee on Genetics ATABRPHC Lawson Wilkins Pediatric Endocrine Society. Foley T.Kaplowitz PB.Kaye CI.Sundararajan S.Varma SK. Update of newborn screening and therapy for congenital hypothyroidism. Pediatrics. 2006;117(6):2290-2303. doi: 10.1542/peds.2006-0915.

27. Talwar N, Mohan S, Ravi B, Andley M, Kumar A. Lithium-induced enlargement of a lingual thyroid. Singapore Med J. 2008 Mar;49(3):254-5.

\section{How to cite this article?}

Maya Menon, Sreejyothi.G, Deepa Binod, Raveendranath K, Riaz I. Case report on congenital hypothyroidism: Early Vs Late Presentation: Int J Pediatr Res 2016;3(2):135-139. doi:10.17511/ijpr.2016.i02.12. 